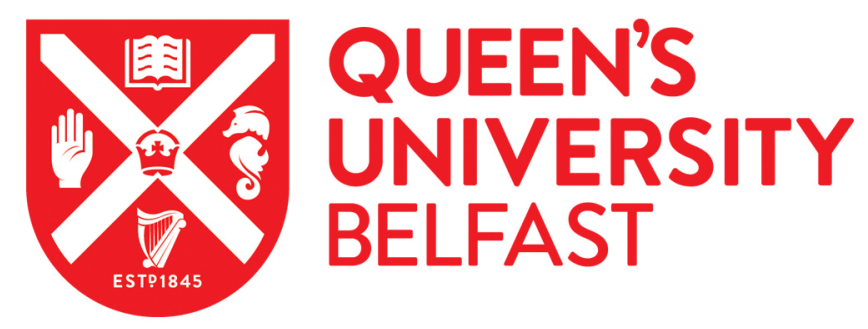

\title{
Compressive strength estimates of adiabatically cured concretes using maturity methods
}

Soutsos, M., Hatzitheodorou, A., Kanavaris, F., \& Kwasny, J. (2019). Compressive strength estimates of adiabatically cured concretes using maturity methods. ASCE Journal of Materials in Civil Engineering, 31(7). https://doi.org/10.1061/(ASCE)MT.1943-5533.0002757

Published in:

ASCE Journal of Materials in Civil Engineering

Document Version:

Peer reviewed version

Queen's University Belfast - Research Portal:

Link to publication record in Queen's University Belfast Research Portal

Publisher rights

Copyright 2019 American Society of Civil Engineers. This work is made available online in accordance with the publisher's policies. Please refer to any applicable terms of use of the publisher.

\section{General rights}

Copyright for the publications made accessible via the Queen's University Belfast Research Portal is retained by the author(s) and / or other copyright owners and it is a condition of accessing these publications that users recognise and abide by the legal requirements associated with these rights.

Take down policy

The Research Portal is Queen's institutional repository that provides access to Queen's research output. Every effort has been made to ensure that content in the Research Portal does not infringe any person's rights, or applicable UK laws. If you discover content in the Research Portal that you believe breaches copyright or violates any law, please contact openaccess@qub.ac.uk. 


\section{Compressive strength estimates of adiabatically cured concretes}

\section{2 using maturity methods}

4 Marios Soutsos* BEng (Hons), $\mathrm{PhD}, \mathrm{MICT}$

5 Professor of Materials/Structures, School of Natural and Built Environment, Queen's

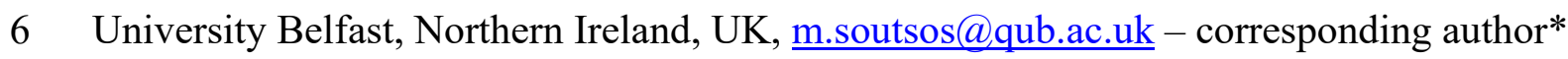

7 Alexandros Hatzitheodorou BEng (Hons), MSc, PhD

8 Civil Engineer Consultant, Athens, Greece, alexengineer30@gmail.com

9 Fragkoulis Kanavaris MEng (Hons), PhD, AMICT, CAPM

10 Concrete Materials Specialist, Formerly in Queen's University Belfast, currently in Advanced

11 Technology \& Research, Arup, London, UK, frag.kanavaris@arup.com

12 Jacek Kwasny BSc Eng, MSc, PhD

13 Research Fellow, School of Natural and Built Environment, Queen's University Belfast,

14 Northern Ireland, UK, j.kwasny@qub.ac.uk

16 Abstract

The strength development of standard and adiabatically cured concretes was determined. The concrete mixes were of 28-day cube strengths of 50 and $30 \mathrm{MPa}$ and also had Portland cement (PC) replaced partially with fly ash (FA) and ground granulated blastfurnace slag (GGBS) at $30 \%$ and $50 \%$, respectively. The peak adiabatic temperature was effectively reduced with GGBS addition but was only reduced with FA addition for the lower w/b concrete. Considerable early age strength enhancements resulted from the adiabatic curing regime. The Nurse-Saul and Arrhenius based maturity functions were used to estimate

24 the increases in early age adiabatic strength. The Nurse-Saul function underestimated the 
effect of high early age curing temperature for all concretes but to a greater extent for those with GGBS and FA whilst the Arrhenius based, which allows for the consideration of an "apparent" activation energy, gave more accurate estimates. Strength estimates for adiabatically cured concretes and isothermally $\left(50{ }^{\circ} \mathrm{C}\right)$ cured mortars were also compared indicating that the latter might have been affected by the detrimental effect of high curing temperatures starting from early age.

\section{Keywords}

"Apparent" activation energy, Maturity functions, Compressive strength development and estimates, Fly ash, Ground granulated blast-furnace slag.

\section{Introduction}

There is a need to understand and quantify the effects of temperature on the early age strength development of concrete mixtures. This need, which has been recognised for a long time from researchers and engineers, has been mainly associated with: a) determining the elevation of curing temperature necessary to achieve the required early age strength (Saul, 1951) which will enable safe lifting of precast concrete structural elements as early as sixteen to eighteen hours after casting and, b) predicting the real-time strength on-site, particularly during cold weather concreting, to allow safe formwork striking and removal of props and ultimately, avoid collapses like the Willow Island one (1978) which resulted in 51 deaths (Lew et al. 1979; Feld and Carper, 1997). This can be accomplished with maturity functions which aim to account for the combined effect of temperature and time on the strength development of concrete (Barnett et al. 2007a; Brooks et al. 2007; Galobardes et al. 2015, Sofi et al. 2012, Yikici et al. 2015; Soutsos et al. 2016a). 

concrete strength irrespective of the combination of time and temperature that make up that maturity:

$$
M=\sum_{t}\left(T-T_{0}\right) \cdot \Delta t
$$

\section{Equation 1}

55

60

61

62

63

64

65

66

67

68

69

\section{6}

where: $\quad \mathrm{M} \quad$ is the maturity $\left({ }^{\circ} \mathrm{C} \cdot\right.$ days $)$,

$\mathrm{T} \quad$ is the average temperature $\left(20^{\circ} \mathrm{C}\right.$ for standard curing $)$ over the time interval $\Delta \mathrm{t}\left({ }^{\circ} \mathrm{C}\right)$,

$\mathrm{T}_{0} \quad$ is the datum temperature $\left({ }^{\circ} \mathrm{C}\right)$,

$\Delta \mathrm{t} \quad$ is the time interval (days).

61 Equation 1, which is what has become known as the Nurse-Saul maturity function, assumes that the strength development rate varies linearly with curing temperature. It can be also be expressed in a form of an equivalent age, in which a given curing history (reckoned in temperature-time) corresponds to an equivalent age of curing at a reference temperature, as given by Equation 2 .

$$
t_{e}=\frac{\sum\left(T-T_{0}\right)}{\left(T_{r}-T_{0}\right)} \cdot \Delta t
$$

\section{Equation 2}

where: $\quad t_{e} \quad$ is the equivalent age at the reference temperature (days), $\mathrm{T}_{\mathrm{r}} \quad$ is the reference temperature $\left({ }^{\circ} \mathrm{C}\right)$. 

has become particularly convenient when it comes to using other formulations besides Equation 1 to account for the combined effects of temperature and time on the strength development of concrete.

The assumption that the strength development rate follows the Arrhenius principle leads to the maturity function shown in Equation 3, which is referred to as Arrhenius function in this study (Freiesleben and Pedersen, 1977).

$$
t_{e}=\sum e^{-\frac{E a}{R} \cdot\left(\frac{1}{T_{a}}-\frac{1}{T_{s}}\right)} \cdot \Delta t
$$

\section{Equation 3}

81

82

The determination of the "apparent" activation energies can be achieved using “equivalent” mortar samples, as recommended by ASTM Standard C1074-98 (ASTM, 2011) and the results can be, subsequently, applied to the concrete under investigation. This requires the determination of strength development under at least three curing temperatures.

Regression analysis is needed in order to relate concrete strength to age or maturity index (Carino, 2004; Freiesleben and Pedersen, 1985; Carino and Tank, 1992). The hyperbolic function proposed by Carino (Carino and Tank, 1992) (Equation 4) is the one suggested by ASTM C1074-11 (ASTM, 2011). 


$$
S=\frac{S_{u} \cdot k \cdot\left(t-t_{0}\right)}{1+k \cdot\left(t-t_{0}\right)}
$$

\section{Equation 4}

where: $\mathrm{S}$ is the compressive strength at age $\mathrm{t}(\mathrm{MPa})$,

$\mathrm{t}$ is the test age (days),

to is the age at which compressive strength development is assumed to begin (days).

The rate constant, $k$, the ultimate strength, $S_{u}$, and the age at which strength development begins, to, of each mortar mixture is determined at all investigated curing temperatures through regression analysis.

ASTM C1074-11 (ASTM, 2011) recommendation for the calculation of the

110 "apparent" activation energy, $E_{a}$, is to plot $\ln (k)$ against $1 / T_{a b s}$ (given in $1 /$ Kelvin), with $T_{a b s}$

111 being the absolute curing temperature. The slope of the trend line, designated as- $Q$, is then 112 obtained from regression analysis and the "apparent" activation energy $\left(E_{a}\right)$ of the mix under 113 investigation will be equal to $Q \cdot R$, with $R$ being the ideal gas constant equal to $8.31 \mathrm{~J} / \mathrm{K} \cdot \mathrm{mol}$.

114 The concrete mixes investigated in the work described herein were those used for the

115 Department of Trade and Industry (DTI) concrete core project (The Concrete Society, 2004).

116 These were of 30 and $50 \mathrm{MPa} 28$-day compressive strength and included partial Portland cement (PC) replacement with ground granulated blast furnace slag (GGBS) and fly ash (FA) at 50 and $30 \%$ cement replacement levels, respectively. The mixes were replicated in the laboratory in order to compare the in-situ strength development, as determined from testing

120 cores obtained from various structural elements, with that of laboratory cast cubes cured in a

121 computer controlled matched curing tank which replicated the in-situ temperature history: 
- Phase I investigated the effect of in-situ temperature on the early age strength development of concretes with GGBS and fly ash (Soutsos et al. 2016), and,

- Phase II investigated the effect of isothermal curing temperature on the strength development of mortar mixes with GGBS and FA (Soutsos et al. 2017).

Accurate strength estimates were obtained for in-situ temperatures around $20{ }^{\circ} \mathrm{C}$

127 (during summer and below this down to $10{ }^{\circ} \mathrm{C}$ during winter) and peak temperatures of $51{ }^{\circ} \mathrm{C}$ and $61{ }^{\circ} \mathrm{C}$ are only reached 33 to 60 hours after casting, e.g. in partially insulated large concrete blocks $1.5 \times 1.5 \times 1.5 \mathrm{~m}$ cast during summer (Soutsos et al. 2016). The effect of high early curing temperatures of up to $50{ }^{\circ} \mathrm{C}$ immediately after casting and cured isothermally at such temperature until tested was investigated in Phase II (Soutsos et al. 2017). The NurseSaul function was found to underestimate the early age strength development at higher temperatures whilst the Arrhenius function overestimated them (Soutsos et al. 2017). There is a need to determine the reasons why maturity functions become inaccurate when high early age curing temperatures are used. Such curing temperatures may nowadays

136 be needed with the new types of cements (CEM II - PC with GGBS, FA, limestone or silica 137 fume, CEM III - PC with GGBS, CEM IV - PC with medium-high volume of siliceous FA and CEM V - composite cement) that have gained popularity due to their lower than CEM I

139 (neat PC) carbon footprint. CEM III/B which contains $66-80 \%$ GGBS is also required for 140 exposure class XS1, XS, and XS3 (corrosion induced by chlorides from sea water) (BSI, 141 2016) and if specified then it is expected to cause production issues for precast concrete 142 factories. The required early age strength as per (BSI, 2014), e.g. 15 and $24 \mathrm{MPa}$ for

143 reinforced and prestressed concretes, respectively, at 16 to 18 hours after casting, may only 144 be achieved with high early age curing temperatures as soon as concrete is cast and without 145 the "delay period" before the "temperature rise period" as is normally recommended for 
146 precasting works (Neville and Brooks, 2010). Thermal activation by use of heated mix water

147 has also been suggested (Reddy and Soutsos, 2016).

148 Earlier work (Soutsos et al. 2017) indicated that the Arrhenius function overestimates

149 early age strength of concretes cured at elevated temperatures and that the reason for this is

150 the detrimental effect on compressive strength. This was believed to be for later age

151 compressive strengths but it now appears to start from a very early age. The early and later 152 age detrimental effects, reported also elsewhere (Sajedi and Razak, 2011; Lothenback et al.

153 2007; Brooks et al. 2007; Carino, 2004; Kim et al. 1998), need to be understood and 154 incorporated into maturity functions to improve strength estimates at early ages. The aim of 155 this investigation was therefore to quantify the detrimental effect of high early age curing 156 temperatures on the compressive strength estimates at early ages, particularly those of the 157 Arrhenius function.

\section{Materials and experimental procedures}

Materials

The objective was to use cement additions, which are also known as cement replacement materials (CRMs), and aggregates that were as similar as possible to those 163 originally used by DTI project.

164 Portland cement with a compressive strength of $57 \mathrm{MPa}$ at 28 days (tested according to BS EN 196-1-2005 (BSI, 2005)), was supplied in bags by British Lime Industries. PC conformed to the requirements of BS EN 197-1:2011 (BSI, 2011). Two CRMs were used to

167 partially replace PC, namely GGBS and FA. GGBS, conforming to BS EN 15167-1:2006 168 (BSI, 2006), was supplied in bags by the Appleby Group. FA, conforming to BS EN 450169 1:2005 (BSI, 2012), was supplied in sealed plastic containers by a coal burning power station, 
170 in Warrington, UK (Soutsos et al. 2016, 2017, 2018). The chemical composition of PC,

171 GGBS and FA are shown in Table 1.

172 Uncrushed 5-20 mm round gravel, supplied by the Fagl Lane quarry (Wales, UK),

173 was used as coarse aggregate in this study. Its water absorption and specific gravity were

$174 \quad 1.7 \%$ and 2.64, respectively. The fine aggregate, also supplied by the Fagl Lan quarry, was

175 well graded and had water absorption and specific gravity of $2.6 \%$ and water absorption of 176 2.60, respectively. The aggregate grading curves and the overall grading limits from 177 BS882:1992 (BSI, 1992) (now replaced by BS EN 12620:2002+A1:2008 (BSI, 2002a)), are 178 shown in Fig. 1.

\section{Concrete mixes investigated}

The concrete mixtures investigated had target 28-day cube compressive strengths of 30 and $50 \mathrm{MPa}$. The neat PC mixes were PC30 and PC50. Mixes with 30\% of the total binder being FA were FA30 and FA50 whilst those with 50\% GGBS were GGBS30 and GGBS50.

184 The mixture proportions of the concrete investigated are shown in Table 2 as are the compressive strengths results for standard $\left(20^{\circ} \mathrm{C}\right)$ and adiabatic curing regimes.

Mixing, casting, curing and testing procedures

The concrete mixtures were prepared using horizontal pan mixer with a capacity of

$1890.1 \mathrm{~m}^{3}$. The cementitious materials and aggregate were firstly introduced to the mixing pan

190 in order to be dry-mixed for approximately one minute. This was then succeeded by adding

191 the water into the mixing pan and the mixing was, subsequently, continued for approximately

192 five minutes. The consistency was evaluated by implementing the slump test in accordance 193 with BS EN 12350-2:2009 (BSI, 2009). Single- and three-gang steel moulds were used to 
cast $100 \mathrm{~mm}$ and $150 \mathrm{~mm}$ size concrete cube specimens. Casting was carried out in two layers with each layer compacted on a vibrating table.

197 Two different curing methods were applied:

198 - Standard curing - The $100 \mathrm{~mm}$ size concrete specimens cast inside single cube moulds were covered with wet hessian and a polythene sheet immediately after casting and left to cure at room temperature conditions (approximately $20^{\circ} \mathrm{C}$ ) (BSI, 2002b). After 24 hours they were demoulded and placed inside a water bath $\left(20^{\circ} \mathrm{C}\right)$.

- Adiabatic curing - The adiabatic temperature rise caused by the cement hydration reaction will occur if heat exchange between fresh concrete and surrounding environment is restricted. To achieve such state, it is required to either provide heavy insulation around the concrete, which will inevitably result in a degree of heat loss, or alternatively, to ensure that the environment surrounding the concrete is at the same, or approximately the same, temperature as the concrete. The latter approach was adopted in this research. A $150 \mathrm{~mm}$ concrete cube was cast in a stainless steel box in which $20 \mathrm{~mm}$ thick expanded polystyrene was lined for thermal insulation and heavyduty polythene to prevent any moisture losses. The specimen was subsequently submerged into a programmable computer controlled curing water tank and two Type-T thermocouples were embedded in it through an opening in the top of the box. Two additional Type-T thermocouples were submerged in the water in the tank in order to continuously monitor its temperature. The thermocouples were all connected to a Pico TC08 data logger and a computer which was recording the temperatures and was also programmed to trigger the water heating system once the difference between the water and the concrete sample temperatures was exceeding $1{ }^{\circ} \mathrm{C}$. It may be assumed, taking into consideration the fact that there has been no drop in temperature 
once the peak had been reached, that there was only a very low amount of heat lost and thus no adjustment was denned necessary for the results. However, even small heat losses during hydration may have still affected the peak temperature. The programmable computer control curing tank used for adiabatic tests is shown in Fig. 2 and a schematic diagram of the setup in Fig. 3. In addition, the three gang-moulds, containing $100 \mathrm{~mm}$ size concrete "companion" specimens, were wrapped after casting with cling film and tape and submerged in the programmable computer controlled curing tank. This allowed for determination of the compressive strength for the adiabatic curing regime.

The specimens cured under standard curing temperature were tested at $1,2,3,5,7$,

$14,28,42,84,156$ and 365 days whilst those cured under adiabatic conditions were tested at were tested in order to derive an average compressive strength.

\section{Results and discussion}

The contribution of GGBS and FA to: (a) the strength development under standard

$\left(20{ }^{\circ} \mathrm{C}\right)$ curing, (b) the adiabatic temperature rise, and (c) the strength development under adiabatic curing is first examined. Subsequently, the applicability/accuracy of different maturity models for estimating the compressive strength development of concretes with CRMs under adiabatic conditions is investigated.

Strength development at $20^{\circ} \mathrm{C}$

The strength development curves for all the six replicated concrete mixes, i.e. PC30 and PC50, GGBS30 and GGBS50, and FA30 and FA50, are shown in Fig. 4(a) whilst the 
hyperbolic function suggested by Carino (Carino and Tank, 1992), see Equation 4, which is also the one recommended by ASTM Standard C1074-11 (ASTM, 2011), was used for the regression curves. The regression analysis constants $S_{u}, k$ and $t_{0}$ obtained are shown in Table 3. It appears that FA30 and FA50 concretes had higher 28-day cube compressive strengths than those of the corresponding PC and GGBS mixtures. The contribution of FA to the longterm compressive strength development also becomes apparent in Fig. 4 whilst compressive strength of GGBS mixtures at early ages is again confirmed to be lower compared to the equivalent ones of PC and even FA mixes. Fig. 4(b) shows the compressive strength versus maturity index as calculated by Equation 1 .

Adiabatic temperature rise

The adiabatic temperature rise of all the investigated concretes is depicted in Fig. 5(a).

The neat PC concretes of 30 and $50 \mathrm{MPa}$ strengths had a temperature rise of $32.5^{\circ} \mathrm{C}$ and 48 ${ }^{\circ} \mathrm{C}$ respectively from a placement temperature of nearly $20{ }^{\circ} \mathrm{C} .50 \%$ GGBS replacement appears to be effective in reducing the adiabatic temperature rise to a considerable extent, i.e. down to $24{ }^{\circ} \mathrm{C}$ and $38{ }^{\circ} \mathrm{C}$ for grades 30 and $50 \mathrm{MPa}$, respectively. $30 \% \mathrm{FA}$ replacement reduced the temperature of the $50 \mathrm{MPa}$ concrete down to $39^{\circ} \mathrm{C}$ but there was no reduction for the $30 \mathrm{MPa}$ concrete. This appears to be abnormal except that FA was not used to replace PC on a weight for weight basis. FA was $30 \%$ of the total binder but, because the concretes were designed to have equal 28-day strength, the FA concrete mixes had higher binder contents, see Table 2; $385 \mathrm{~kg} / \mathrm{m}^{3}$ for FA50 compared to $330 \mathrm{~kg} / \mathrm{m}^{3}$ for PC50 and $275 \mathrm{~kg} / \mathrm{m}^{3}$ for FA30 compared to $240 \mathrm{~kg} / \mathrm{m}^{3}$ for PC 30 . Also, to achieve the target strength grades, the $\mathrm{w} / \mathrm{b}$ ratios of FA concretes were lower than those of comparable PC mixes (Table 2). The total heat emitted per kilogram of binder in the concrete at any time during the adiabatic test can be calculated from the following expression (Ballim and Graham, 2005): 


$$
q_{b}(t)=C_{p} \times\left(T_{t}-T_{0}\right) \times \frac{\gamma_{c}}{b_{c}}
$$

Equation 5

where: $\mathrm{q}_{\mathrm{b}}$ is the heat output per kilogram of binder at time $\mathrm{t}(\mathrm{kJ} / \mathrm{kg})$,

$\mathrm{C}_{\mathrm{p}}$ is the specific heat capacity of concrete $\left(\mathrm{J} / \mathrm{kg} \cdot{ }^{\circ} \mathrm{C}\right)$, taken as $880 \mathrm{~J} / \mathrm{kg} \cdot{ }^{\circ} \mathrm{C}$

$\mathrm{T}_{\mathrm{t}}$ is the temperature of the concrete at time $\mathrm{t}\left({ }^{\circ} \mathrm{C}\right)$,

$\mathrm{T}_{0}$ is the temperature of the concrete at the beginning of the test $\left({ }^{\circ} \mathrm{C}\right)$,

$\gamma_{c} \quad$ is the density of the concrete $\left(\mathrm{kg} / \mathrm{m}^{3}\right)$.

$b_{c} \quad$ is the binder content of the concrete $\left(\mathrm{kg} / \mathrm{m}^{3}\right)$

The binder heat output for PC50 and PC30 was $288 \mathrm{~kJ} / \mathrm{kg}$ and $281 \mathrm{~kJ} / \mathrm{kg}$, for FA50 and FA30 was $210 \mathrm{~kJ} / \mathrm{kg}$ and $242 \mathrm{~kJ} / \mathrm{kg}$ and for GGBS50 and GGBS30 was $239 \mathrm{~kJ} / \mathrm{kg}$ and $217 \mathrm{~kJ} / \mathrm{kg}$, respectively, see Fig. 5(b). Both FA and GGBS reduced the heat output (kJ) per kilogram of binder. However, in increasing the binder content to achieve similar 28-day strengths to PC, the FA30 had similar temperature rise to that of PC30. The higher strength mixtures as expected achieve higher temperatures, despite that the heat output per kilogram of binder is slightly reduced at the lower w/b ratios, particularly for the FA concretes. This has also been reported by others (Kanavaris, 2017; Turu'allo, 2013; Riding et al. 2012; Hatzitheodorou, 2007; Pane and Hansen, 2005; Zhang et al. 2002).

\section{Effect of adiabatic temperature rise on strength development}

The strength development of all concrete mixes cured under adiabatic conditions is shown in Fig. 6. All the concretes benefited from the adiabatic temperature rise and had much higher early age strengths than when cured at $20{ }^{\circ} \mathrm{C}$. The most benefit for the GGBS concrete appears to be at 2 or even 3 days and this is confirmed by plotting the adiabatic (Sadiabatic) to 
294 standard $\left(\mathrm{S}_{20}{ }^{\circ} \mathrm{C}\right)$ curing relative strengths as shown in Fig. 7. This is because GGBS reduces

295 not only the temperature rise but also the rate of temperature rise at early ages. The peak

296 temperature of concretes with GGBS is reached after the first day and therefore a more

297 marked improvement in strength is obtained at 2 and 3 days rather than one day.

298 The improvements in the compressive strengths relative to each mixture's standard

299 28-day $\left(20^{\circ} \mathrm{C}\right)$ curing strength, i.e. $\left(\mathrm{S}_{\text {adiabatic }} / \mathrm{S}_{28-d a y,} 2{ }^{\circ} \mathrm{C}\right)$, see Fig. 8, show that the strengths of

300 FA and GGBS mixes are still lower than the adiabatically cured PC concretes at early ages.

301 This is despite that the strength improvement of FA and GGBS mixes is more significant than

302 the corresponding PC mixes. Even the moderate improvement to PC strengths has maintained

303 their strength above those with GGBS and FA at least for the first day if not for up to 3 days.

304 The "cross-over" effect i.e. high curing temperature results in a greater strength than a low 305 curing temperature at early ages, and conversely results in lower strength at later maturities

306 (McIntosh, 1956), is less apparent for the adiabatically cured specimens than it was for

307 isothermally cured specimens (Soutsos et al. 2017). The PC50 mix shows "cross-over" 308 between three and five days whilst the PC30's only occurs at 28-days. The "cross-over" for

309 GGBS and FA mixes is not apparent within the first 28 days but it is likely that this will 310 occur at later ages, see Fig. 6.

311 The improvement of strength, in terms of the adiabatic strength (Sadiabatic) to the 312 standard curing strength $\left(\mathrm{S}_{20}{ }^{\circ} \mathrm{C}\right)$ for the FA mixes seems to be similar to that of PC concretes 313 with $30 \mathrm{MPa}$ strength and remarkably better for the $50 \mathrm{MPa}$, see Fig. 9. The latter seems to

314 indicate that FA contributes significantly to the strength even at low water to binder ratios 315 whilst at the same time reducing the temperature rise of the concretes. 
The only requirement of Nurse-Saul function in order to calculate the maturity index

319 according to Equation 1 or the equivalent age according to Equation 2, is the temperature

320 history of the concrete. Conversely, in addition to the temperature history, the Arrhenius

321 function also required the "apparent" activation energies, $E_{a}$, of concretes under investigation.

322 These were previously determined (Soutsos et al. 2017) according to ASTM C1074-11

323 (ASTM, 2011) proceedure and they were 37.4, 22.5 and $52.8 \mathrm{~kJ} / \mathrm{mol}$ for PC30, FA30 and

GGBS30 and 29.7, 27.3 and $41.6 \mathrm{~kJ} / \mathrm{mol}$ for PC50, FA50 and GGBS50 respectively. These

$E_{a}$ values are in good agreement with those found in the literature (Soutsos et al. 2013; Poole

et al. 2010; Barnet et al. 2007b; Poole et al. 2007; Barnett et al. 2006). Equation 3 was used to calculate the Arrhenius equivalent age $t_{e}$ at time $t$. The specified reference temperature, $T_{s}$, used was $293{ }^{\circ} \mathrm{K}\left(20{ }^{\circ} \mathrm{C}\right) . \mathrm{T}_{\mathrm{a}}\left(\right.$ in $\left.{ }^{\circ} \mathrm{K}\right)$ was the average concrete temperature during time interval $\Delta t$, i.e. the recorded adiabatic temperature histories. The calculated equivalent age, $t_{e}$, was then substituted for $t$ in Equation 4 with regression constants $S_{u}, k$ and $t_{0}$, as previously determined for the strength results obtained for the concrete cured at the reference temperature $\left(20^{\circ} \mathrm{C}\right)$, see Table 2 .

The adiabatic temperature histories, Fig. 6, were converted, using the strength-time and Arrhenius equations, into estimated strength development curves and these are shown in

Fig. 10 and Fig. 11. The Nurse-Saul function underestimated the strength development, especially at early ages, for all but $50 \mathrm{MPa}$ strength concretes. This is in agreement with previous findings for isothermally cured "equivalent" mortars at $50{ }^{\circ} \mathrm{C}$ which are also shown on Fig. 12 and Fig. 13 for comparison (Soutsos et al. 2017). However, the overestimation of strength at later ages is delayed for adiabatic curing regime. The overestimation of strengths is due to the incapability of the Nurse-Saul function to account for the detrimental effect high

341 temperatures at early ages have on later age strength (Soutsos et al. 2017). As mentioned 
342 earlier, in the adiabatic curing regime, the temperature rise depends on the heat evolution

343 from the cementitious binder. The temperature increase is delayed by several hours and

344 notable rises only occur even more hours later as a result of the dormant period (Shi et al.

345 2006). As the hydration reaction is required to have evolved significantly prior to any high

346 temperatures occurring, the detrimental effect on long-term strengths is considerably reduced.

347 It is also for this reason that it is suggested that curing cycles, e.g. for precast concrete 348 elements, should have a "delay period" before the "temperature rise period" (Neville and 349 Brooks, 2011).

350 The strength estimates from the Arrhenius function for the adiabatically cured concretes show a significant improvement to the estimates for the isothermally cured concretes (Soutsos et al. 2017), see Fig. 12 and Fig. 13. The improvement is with regards to the over-estimation of strengths, at even early ages, which was suspected to be due to the detrimental effect of high curing temperatures starting from early age for isothermally cured mortars (Soutsos et al. 2017). The only concrete that still showed detrimental effect from high early age curing temperature was PC50 which had a significant temperature rise of $37{ }^{\circ} \mathrm{C}$ within 12 hours after casting. The Arrhenius function overestimates the early age strengths for this concrete but to a lesser extent than it did for the $50{ }^{\circ} \mathrm{C}$ isothermally cured specimens.

\section{Conclusions}

The strength development of isothermally $\left(20^{\circ} \mathrm{C}\right)$ and adiabatically cured concretes was determined. It was found that:

- GGBS was efficient in reducing considerably the adiabatic peak temperature rise.

- FA was only efficient in reducing considerably the adiabatic peak temperature rise for the high, $50 \mathrm{MPa}$, compressive strength which had a lower water-binder ratio. 
- Significant increases in early age strength resulted from the adiabatic curing regime despite that considerable temperature rises did not occur until after 12 hours and peak temperatures only after 24 hours.

- The "delay period" before the "temperature rise period" of the adiabatic curing regime was sufficient to reduce or delay the "cross-over" effect to beyond 28-days for all mixes other than PC50. concretes. It was found that:

- The Nurse-Saul function underestimated the improvements in the early age strengths resulting from the higher "curing" temperatures of the adiabatic curing regime. It is believed that this occurred because it assumes that the concrete strength gain rate varies linearly with temperature and is the same for all binders.

- The Arrhenius based function was found to be more accurate and this is because it maturity functions or develop improved ones for better estimates of both early age and longterm strength development with and without cement replacement materials. allows for an exponential strength gain rate with temperature relationship.

- The Arrhenius based function strength estimates were significantly better for the adiabatically cured concretes than for the $50{ }^{\circ} \mathrm{C}$ isothermally cured ones. The latter are believed to have been affected by the detrimental effect of high curing temperatures starting from early age.

Ongoing work is aiming to determine modifications to the currently available

\section{Acknowledgements}


392 Hatzitheodorou at the University of Liverpool as part of his $\mathrm{PhD}$ research. The authors are

393 grateful to the School of Engineering, the University of Liverpool for the facilities provided

394 and to the Engineering and Physical Sciences Research Council, UK (GR/R83880/01), for the

395 financial support received for the equipment. The authors would like to thank Dr L.K.A.

396 Sear at United Kingdom Quality Ash Association (UKQAA) for the extensive advice

397 received during the project.

398

399

$400 \quad$ Notations

401 The following symbols are used in this paper:

$402 E_{a}=$ "apparent" activation energy $(\mathrm{J} / \mathrm{mol})$;

$403 k=$ the rate constant (1/day);

$404 \quad M=$ Nurse-Saul maturity $\left({ }^{\circ} \mathrm{C} \cdot\right.$ days $)$;

$405 R=$ universal gas constant $\left(\mathrm{J} /{ }^{\circ} \mathrm{K} \cdot \mathrm{mol}\right)$;

$406 S=$ compressive strength $(\mathrm{MPa})$;

$407 S_{u}=$ ultimate compressive strength $(\mathrm{MPa})$;

$408 T=$ average temperature $\left({ }^{\circ} \mathrm{K}\right.$ or $\left.{ }^{\circ} \mathrm{C}\right)$;

$409 T_{0}=$ datum temperature $\left({ }^{\circ} \mathrm{C}\right)$;

$410 T_{r}=$ specified reference temperature $\left({ }^{\circ} \mathrm{K}\right.$ or $\left.{ }^{\circ} \mathrm{C}\right) ;$

$411 t_{0}=$ age at which compressive strength development is assumed to begin (days);

$412 t_{e}=$ equivalent age (days);

$413 \beta=$ age conversion factor;

$414 \Delta t=$ time interval (days).

415 


\section{References}

ASTM (2011). "Standard practice for estimating concrete strength by the maturity method." ASTM C1074-11, West Conshohocken, Pennsylvania, USA, ASTM International.

Ballim, Y., and Graham, P.C. (2005). "A maturity approach to the heat evolution of concrete." Magazine of Concrete Research, 55(3), pp. 249-256.

Barnett, S.J., Soutsos, M.N., Millard, S.G., and Bungey, J.H. (2006). "Strength development of mortars containing ground granulated blast-furnace slag: Effect of curing temperature and determination of apparent activation energies." Cement and Concrete Research, 36(3) pp. 434-440.

Barnett, S.J., Soutsos, M.N., Bungey, J.H., and Millard, S.G. (2007a). "Fast-Track Construction with Slag Cement Concrete: Adiabatic Strength Development and Strength Prediction.” ACI Materials Journal, 104(4), pp. 388-396.

Barnett, S.J., Soutsos, M.N., Millard, S.G., and Bungey, J.H. (2007b). “Temperature Rise and Strength Development in Laboratory-Cast Structural Elements Containing Slag." American Concrete Institute SP-242: Ninth CANMET/ACI International Conference on Fly Ash, Silica Fume, Slag and Natural Pozzolans in Concrete (Malhotra VM 
442 Brooks, A.G., Schindler, A.K., and Barnes, R.W. (2007). "Maturity method evaluated for various cementitious materials." Journal of Materials on Civil Engineering, 19(12), pp. 1017-1025.

BSI (British Standards Institution). (1992). "Specification for aggregates from natural sources for concrete.” $B S$ 882:1992, London, UK.

BSI (British Standards Institution). (2016). "Concrete - Complementary British standard to BS EN 206 - Part 1: Method of specifying and guidance for the specifier.” BS 85001:2015+A1:2016, London, UK.

BSI (British Standards Institution). (2011). "Cement. Composition, specifications and conformity criteria for common cements.” BS EN 197-1:2011, London, UK.

BSI (British Standards Institution). (2009). "Testing fresh concrete. Slump-test." BS EN 12350-2:2009, London, UK.

BSI (British Standards Institution). (2002a). “Aggregates for concrete." $B S E N$ 12620:2002+A1:2008, London, UK.

BSI (British Standards Institution). (2002b). "Testing hardened concrete. Compressive strength of test specimens.” BS EN 12390-3:2002, London, UK.

BSI (British Standards Institution). (2005). "Methods of testing cement. Determination of strength.” BS EN 196-1-2005, London, UK.

BSI (British Standards Institution). (2012). "Fly ash for concrete. Definition, specifications and conformity criteria." $B S E N$ 450-1:2012, London, UK.

462 BSI (British Standards Institution). (2016). "Design and use of insert of lifting and handling of precast concrete elements." PD CEN/TR 15728:2016, London, UK.

464 BSI (British Standards Institution). (2006) "Ground granulated blast furnace slag for use in concrete, mortar and grout. Definitions, specifications and conformity criteria." $B S$ 
467 Carino, N.J., and Tank, R.C., (1992). "Maturity Functions for Concretes Made with Various Cements and Admixtures." ACI Material Journal, 89(2), pp. 188-196.

Carino, N.J. (2004). “The Maturity Method, In: Handbook on Nondestructive Testing of Concrete." (Malhotra VM and Carino NJ (eds)), 2nd ed. CRC Press, pp. 5.1-5.47.

Feld, J., and Carper, K. (1997). “Construction Failure.” John Wiley and Sons, New York.

Freiesleben, H.P., and Pedersen, E.J. (1977). "Maturity computer for controlled curing and hardening of concrete." Nord. Betong, 1(19).

Freiesleben, H.P., and Pedersen, E.J. (1985). "Curing of concrete structures." $C E B$ Information Bulletin, 166.

Galobardes, I., Cavalaro, S., Goodier, C.I., Austin, S., and Rueda, Á. (2015). "Maturity method to predict the evolution of the properties of sprayed concrete." Construction and Building Materials, 79, pp. 357-369.

Hatzitheodorou, A. (2007). "Insitu Strength Development of Concretes with Cement replacement materials." PhD thesis, University of Liverpool, UK.

Kanavaris, F. (2017). "Early age behaviour and cracking risk of concretes containing GGBS." PhD Thesis, Queen's University Belfast, UK.

Kim, J.-K., Moon, Y.-H., and Eo, S.-H. (1998). "Compressive strength development of 484 concrete with different curing time and temperature." Cement and Concrete Research, 28(12), pp. 1761-1773.

Lew, H., Fattel, S., Shaver, J., Reinhold, T., and Hunt, B. (1979). "Investigation of 487 construction failure of reinforced concrete cooling tower at Willow island." West Virginia Final Report (No. PB-80-192883), National Engineering Lab (NBS), Washington.

490 Lothenbach, B., Winnefeld, F., Alder, C., Wieland, E., and Lunk, P. (2007). "Effect of 
temperature on the pore solution, microstructure and hydration products of Portland cement pastes." Cement and Concrete Research, 37(4), pp. 483-491.

McIntosh, J.D. (1956). "The effects of low-temperature curing on the compressive strength of concrete." In Proceedings of RILEM symposium on winter concreting, Session BII, Copenhagen: Danish Institute for Building Research.

Neville, A.A., and Brooks, J.J. (2010). “Concrete Technology." Pearson Education, $2^{\text {nd }}$ Edition, p. 188.

Pane, I., and Hansen, W. (2005). "Investigation of blended cement hydration by isothermal calorimetry and thermal analysis." Cement and Concrete Research, 35, pp. 11551164.

Poole, J.L., Riding, K.A., Folliard, K.J., Juenger, M.C.G., and Schindler, A.K. (2007). "Methods for calculating apparent activation energy for Portland cement." $A C I$ Materials Journal, 104(1), pp. 303-311.

Poole, J.L., Riding, K., Juenger, M.C.G., Folliard, K.J., and Schindler, A.K. (2010). "Effects

Rastrup, E. (1954). "Heat of hydration in concrete." Magazine of Concrete Research, 6(17), pp. 79-92.

Reddy, J., and Soutsos, M. (2016). “Thermal activation of low carbon precast concrete.” In: Jones, M.R., Newlands, M.D., Halliday, J.E., Csetenyi, L.J., Zheng, L., McCarthy, "Modeling hydration of cementitious systems." ACI Materials Journal, 109(2), pp. 225-234. 
516 Sajedi, F., and Razak, H.A. (2011). "Effects of curing regimes and cement fineness on the compressive strength of ordinary Portland cement mortars." Construction and Building Materials, 25(4), pp. 2036-2045.

Saul, A.G.A., (1951). "Principles underlying the steam curing of concrete at atmospheric pressure." Magazine of Concrete Research, 2(6), pp. 127-140.

Shi, C., Krivenko, P., and Roy, D. (2006). “Alkali-Activated Cements and Concretes.” Taylor \& Francis, p. 65 .

Sofi, M., Mendis, P.A., and Baweja, D. (2012). "Estimating early-age in situ strength development of concrete slabs." Construction and Building Materials, 29, pp. 659666.

Soutsos, M.N., Turu'allo, G., Owens, K., Kwasny, J., Barnett, S.J., and Basheer, P.A.M. (2013). "Maturity Testing of Lightweight Self-Compacting and Vibrated Concretes." Construction and Building Materials, 47, pp. 118-125.

Soutsos, M.N., Hatzitheodorou, A., Kwasny, J., and Kanavaris, F. (2016). "Effect of in situ temperature on the early age strength development of concretes with cement replacement materials." Construction and Building Materials 103, pp. 105-116.

Soutsos, M.N., Hatzitheodorou, A., Kanavaris, F., and Kwasny, J. (2017). "Effect of temperature on the strength development of mortar mixes with GGBS and fly ash." Magazine of Concrete Research, 69(15), pp. 787-801. e00183.

The Concrete Society (2004). "In situ concrete strength. An investigation into the relationship between core strength and standard cube strength." Concrete Society Project Report No. 3, The Concrete Society, Crowthorne, UK, 55 pp. 
541 Turu'allo, G. (2013). "Early age strength development of GGBS concrete cured under different temperatures." PhD thesis, University of Liverpool, UK.

543 Yikici, T.A., and Chen, H. (2015). "Use of maturity method to estimate compressive strength of mass concrete.” Construction and Building Materials, 95, pp. 802-812.

Zhang, Y., Sun, W. and Liu, S. (2002). "Study on the hydration heat of binder paste in highperformance concrete." Cement and Concrete Research, 32, pp. 1483-1488.

\section{List of figure captions:}

554 Fig. 1. Sieve analysis of coarse and fine aggregate

555 Fig. 2. The computer controlled temperature matched curing (TMC) tank for adiabatic tests

Fig. 3. Schematic diagram of the computer controlled TMC tank setup for the adiabatic tests

Fig. 4. Strength development regression analysis plots of laboratory replicated DTI concrete mixes (standard $20^{\circ} \mathrm{C}$ curing)

559 Fig. 5. a) Adiabatic temperature rise of investigated mixes and b) Total cumulative heat 560 output of binder

561 Fig. 6. Strength development of standard $\left(20^{\circ} \mathrm{C}\right)\left(\mathrm{S}_{20}{ }^{\circ} \mathrm{C}\right)$ and adiabatically $\left(\mathrm{S}_{\text {adiabatic }}\right)$ cured 562 concretes

563 Fig. 7. Relative strengths, i.e. $\left(\mathrm{S}_{\text {adiabatic }} / \mathrm{S}_{20}{ }^{\circ} \mathrm{C}\right)$

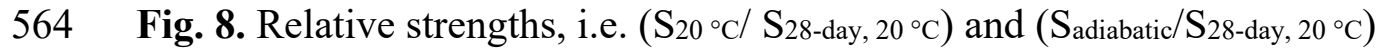

565 Fig. 9. Relative strengths, i.e. $\left(\mathrm{S}_{\text {adiabatic }} / \mathrm{S}_{\text {adiabatic, } \mathrm{PC}}\right)$ and $\left(\mathrm{S}_{20}{ }^{\circ} \mathrm{C} / \mathrm{S}_{20}{ }^{\circ} \mathrm{C}, \mathrm{PC}\right)$ 
566 Fig. 10. Adiabatic strength estimates for $50 \mathrm{MPa}$ strength concretes

567 Fig. 11. Adiabatic strength estimates for $30 \mathrm{MPa}$ strength concretes

568 Fig. 12. Ratio of estimated/actual strength for $50 \mathrm{MPa}$ strength adiabatically cured concretes 569 and also for their $50{ }^{\circ} \mathrm{C}$ isothermally cured "equivalent" mortars

570 Fig. 13. Ratio of estimated/actual strength for $30 \mathrm{MPa}$ strength adiabatically cured concretes

571 and also for their $50{ }^{\circ} \mathrm{C}$ isothermally cured "equivalent" mortars 


\section{Tables}

574 Table 1. Chemical composition of PC, GGBS and FA

\begin{tabular}{cccc}
\hline \multicolumn{4}{c}{ Chemical composition (\% by weight) } \\
\hline Chemical constituent & $\mathrm{PC}$ & GGBS & FA \\
\hline $\mathrm{SiO}_{2}$ & 20.11 & 35.35 & 48 \\
$\mathrm{Al}_{2} \mathrm{O}_{3}$ & 5.16 & 14 & 27 \\
$\mathrm{Fe}_{2} \mathrm{O}_{3}$ & 3.14 & 0.36 & 9 \\
$\mathrm{CaO}$ & 65.49 & 41.41 & 3.3 \\
$\mathrm{MgO}$ & 0.8 & 7.45 & 2 \\
$\mathrm{SO}$ & 3.22 & 0.1 & 0.6 \\
$\mathrm{~K}_{3} \mathrm{O}$ & 0.59 & - & 3.8 \\
$\mathrm{Na}_{2} \mathrm{O}$ & 0.13 & - & 1.2 \\
$\mathrm{CaCO}_{3}$ & 4.47 & - & - \\
Equiv. Alks Na $2 \mathrm{Oe}$ & 0.52 & - & - \\
Free Lime & 1.79 & - & - \\
$\mathrm{Chloride}$ & $71 \mathrm{ppm}$ & - & - \\
LOI & 2.8 & 0.31 & 4.9 \\
\hline
\end{tabular}

575 
577 Table 2. Mix proportions of concrete mixes investigated as well as their compressive strength

578 for $20{ }^{\circ} \mathrm{C}$ and adiabatic curing regimes

\begin{tabular}{|c|c|c|c|c|c|c|}
\hline \multirow{2}{*}{ Material } & \multicolumn{6}{|c|}{ Mix ID } \\
\hline & PC30 & GGBS30 & FA30 & PC50 & GGBS50 & FA50 \\
\hline Cement $\left[\mathrm{kg} / \mathrm{m}^{3}\right]$ & 240 & 115 & 193 & 345 & 165 & 270 \\
\hline GGBS $\left[\mathrm{kg} / \mathrm{m}^{3}\right]$ & - & 115 & - & - & 165 & - \\
\hline FA $\left[\mathrm{kg} / \mathrm{m}^{3}\right]$ & - & - & 82 & - & - & 115 \\
\hline Gravel $\left[\mathrm{kg} / \mathrm{m}^{3}\right]$ & 1102 & 1187 & 1319 & 1205 & 1151 & 1250 \\
\hline Sand $\left[\mathrm{kg} / \mathrm{m}^{3}\right]$ & 799 & 721 & 560 & 615 & 683 & 533 \\
\hline $\begin{array}{c}\text { Free water } \\
{\left[\mathbf{k g} / \mathbf{m}^{3}\right]}\end{array}$ & 158 & 150 & 144 & 160 & 165 & 135 \\
\hline $\begin{array}{c}\text { Total water } \\
{\left[\mathrm{kg} / \mathrm{m}^{3}\right]}\end{array}$ & 198 & 190 & 181 & 197 & 203 & 171 \\
\hline Free w/b & 0.66 & 0.65 & 0.52 & 0.46 & 0.50 & 0.35 \\
\hline Total w/b & 0.83 & 0.82 & 0.66 & 0.57 & 0.61 & 0.44 \\
\hline Slump [mm] & 150 & 120 & 120 & 135 & 120 & 100 \\
\hline
\end{tabular}

\begin{tabular}{|c|c|c|c|c|c|c|c|c|c|c|c|c|}
\hline \multirow{2}{*}{ Testing age [days] } & \multicolumn{12}{|c|}{ Compressive strength $[\mathrm{MPa}]\left(20^{\circ} \mathrm{C} \mid\right.$ Adiabatic $)$} \\
\hline & $20^{\circ} \mathrm{C}$ & Ad. & $20^{\circ} \mathrm{C}$ & Ad. & $\begin{array}{l}\mathbf{2 0} \\
{ }^{\circ} \mathrm{C}\end{array}$ & Ad. & $20^{\circ} \mathrm{C}$ & Ad. & $20^{\circ} \mathrm{C}$ & Ad. & $20^{\circ} \mathrm{C}$ & Ad. \\
\hline 1 & 7 & 13 & 2 & 3 & 7 & 12 & 21 & 31 & 5 & 12 & 13 & 24 \\
\hline 2 & 13 & 22 & 4 & 9 & 13 & 20 & 30 & 35 & 10 & 28 & 22 & 38 \\
\hline 3 & 18 & 25 & 7 & 14 & 17 & 25 & 35 & 37 & 15 & 37 & 28 & 46 \\
\hline 5 & 20 & 26 & 10 & 21 & 21 & 32 & 41 & 39 & 21 & 43 & 34 & 53 \\
\hline 7 & 23 & 29 & 13 & 25 & 24 & 34 & 43 & 39 & 26 & 42 & 38 & 56 \\
\hline 14 & 28 & 29 & 19 & 29 & 28 & 39 & 47 & 41 & 34 & 45 & 43 & 56 \\
\hline 28 & 31 & 31 & 25 & 31 & 35 & 39 & 50 & 49 & 42 & 47 & 51 & 57 \\
\hline 42 & 32 & - & 28 & - & 37 & - & 53 & - & 43 & - & 58 & - \\
\hline 84 & 33 & - & 31 & - & 46 & - & 55 & - & 51 & - & 59 & - \\
\hline 156 & 33 & - & 34 & - & 47 & - & 59 & - & - & - & 66 & - \\
\hline 365 & 32 & - & 37 & - & 47 & - & 56 & - & - & - & 67 & - \\
\hline
\end{tabular}


581 Table 3. Regression parameters (obtained from Equation 4) for $20{ }^{\circ} \mathrm{C}$ strength development

\begin{tabular}{ccccccc}
\hline Mix ID & PC30 & GGBS30 & FA30 & PC50 & GGBS50 & FA50 \\
\hline $\mathrm{S}_{\mathrm{u}}(\mathrm{MPa})$ & 33.36 & 36.91 & 46.35 & 55.49 & 55.70 & 63.93 \\
$\mathrm{k}(1 /$ day $)$ & 0.37 & 0.08 & 0.15 & 0.56 & 0.11 & 0.22 \\
$\mathrm{t}_{0}$ (days) & $2.45 \mathrm{E}-01$ & $1.99 \mathrm{E}-01$ & $7.50 \mathrm{E}-09$ & $2.49 \mathrm{E}-09$ & $1.30 \mathrm{E}-09$ & $6.33 \mathrm{E}-09$ \\
\hline
\end{tabular}

582 


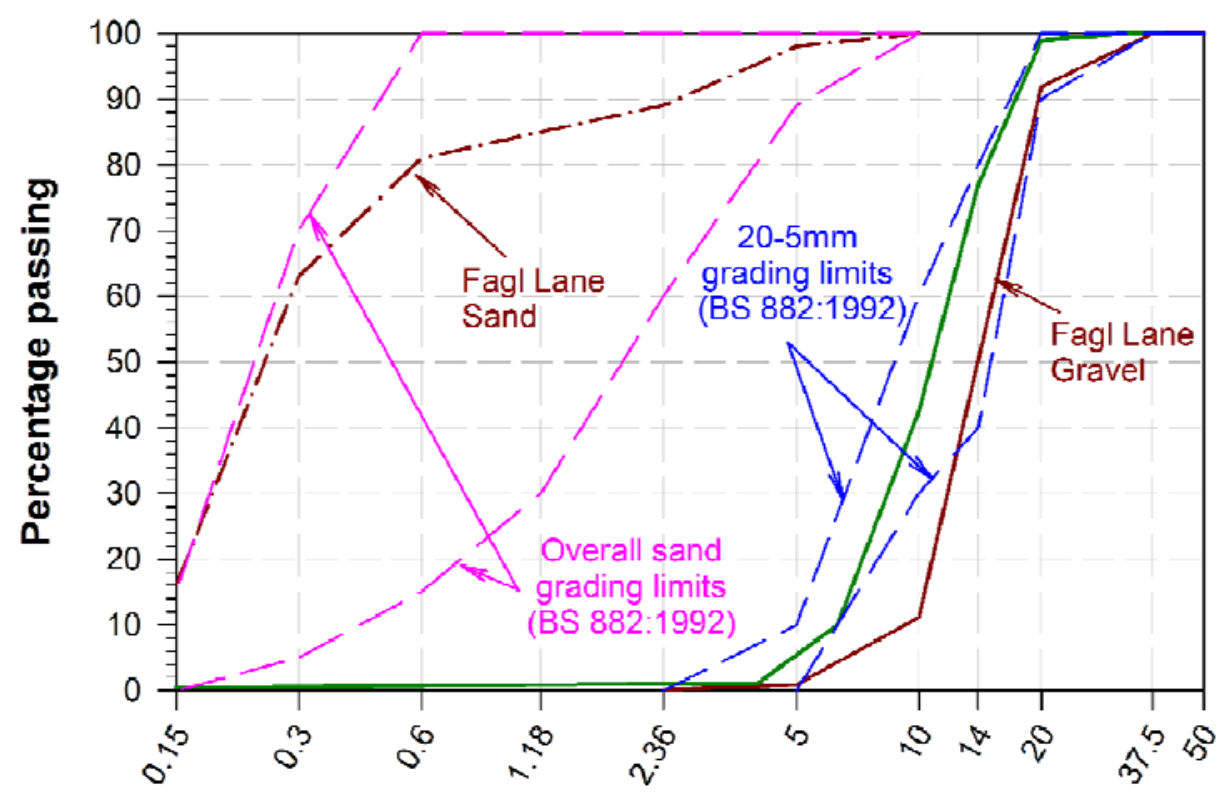

585 Fig. 1. Sieve analysis of coarse and fine aggregate 


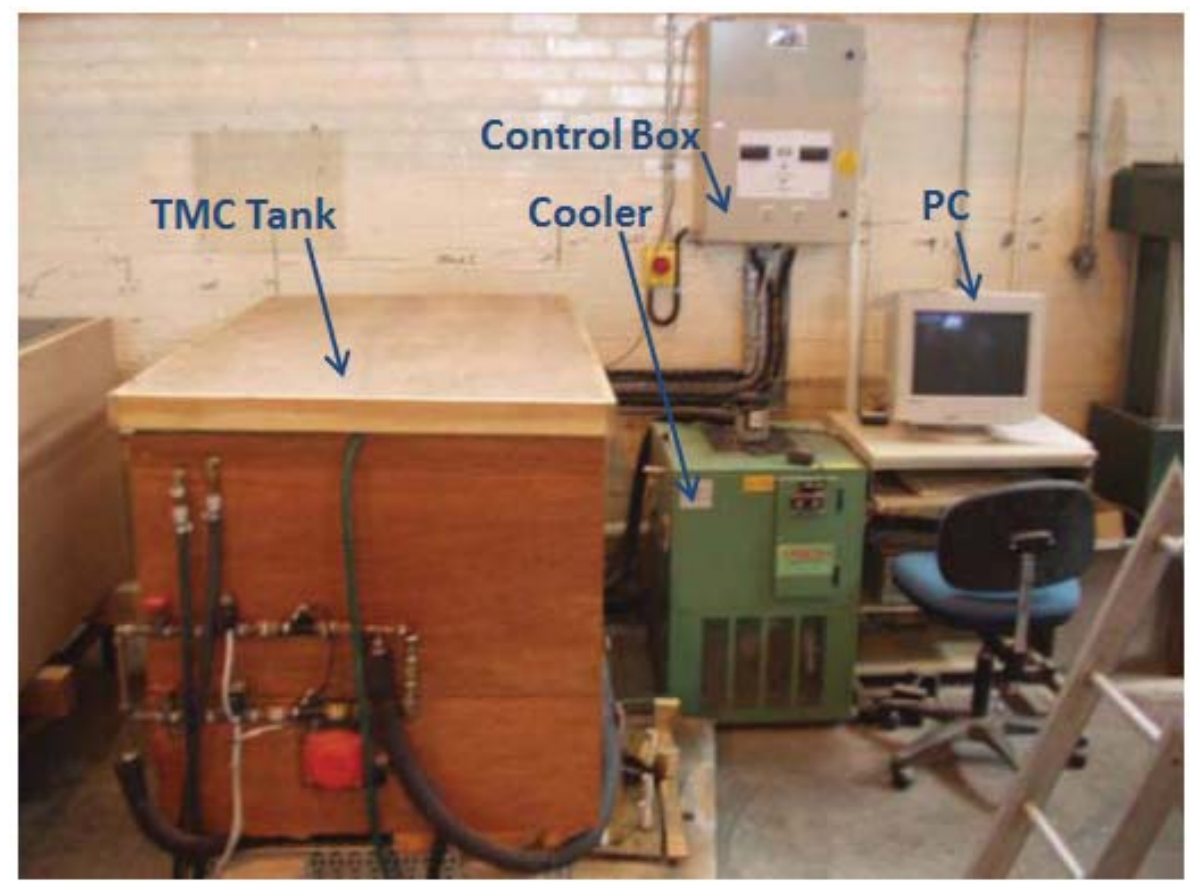

588 Fig. 2. The computer controlled temperature matched curing (TMC) tank for adiabatic tests 


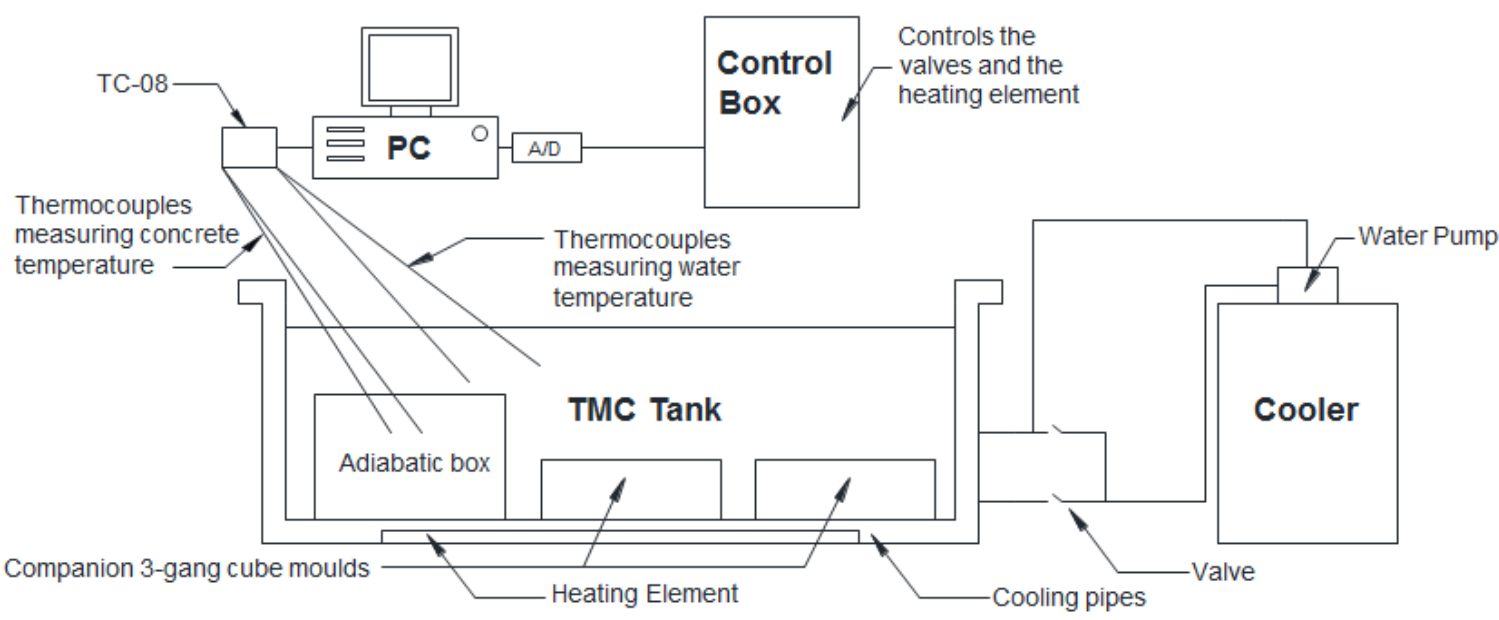

591 Fig. 3. Schematic diagram of the computer controlled TMC tank setup for the adiabatic tests 


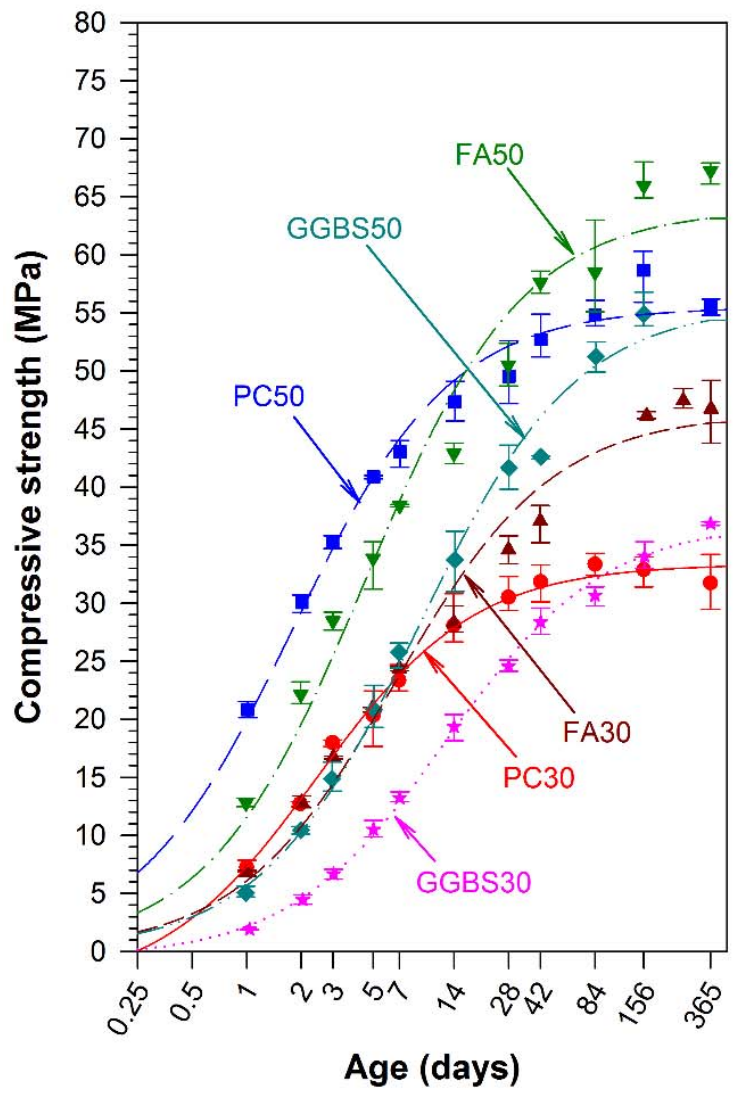

a) Strength vs Age

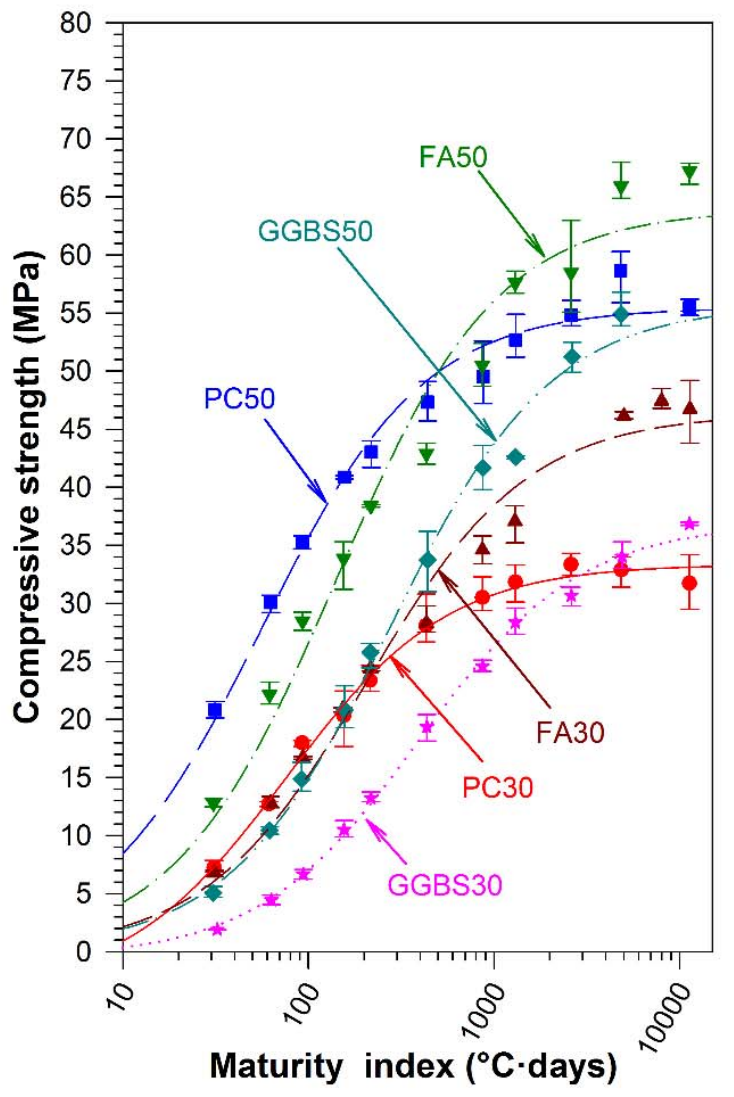

b) Strength vs Maturity index

594 Fig. 4. Strength development regression analysis plots of laboratory replicated DTI concrete 595 mixes (standard $20{ }^{\circ} \mathrm{C}$ curing) 


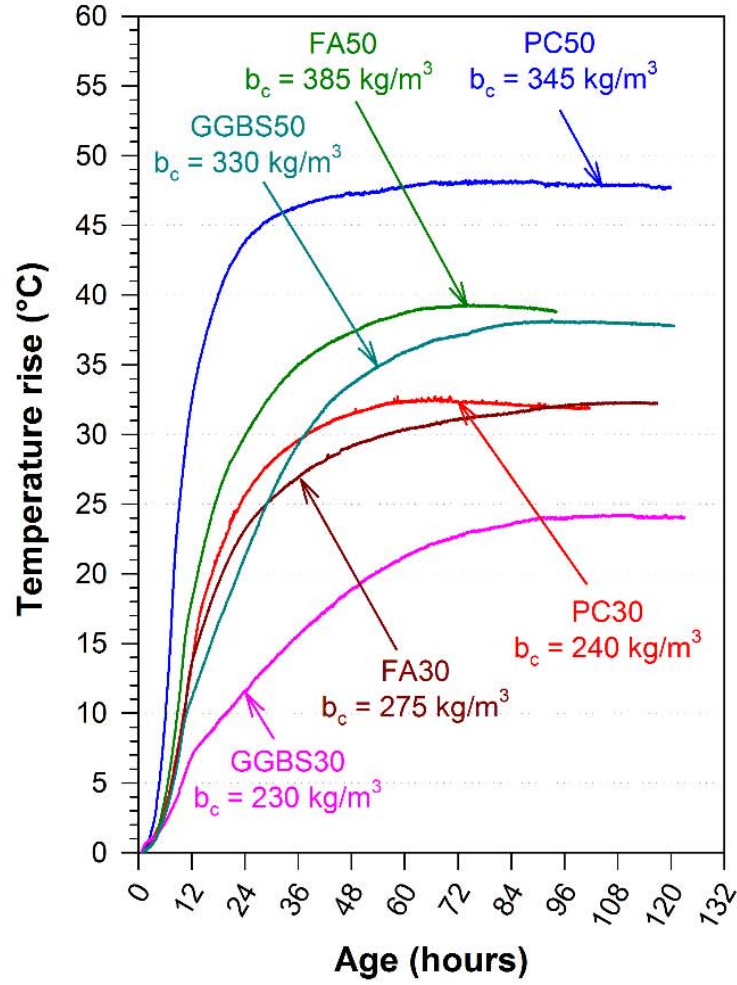

a) Adiabatic temperature rise

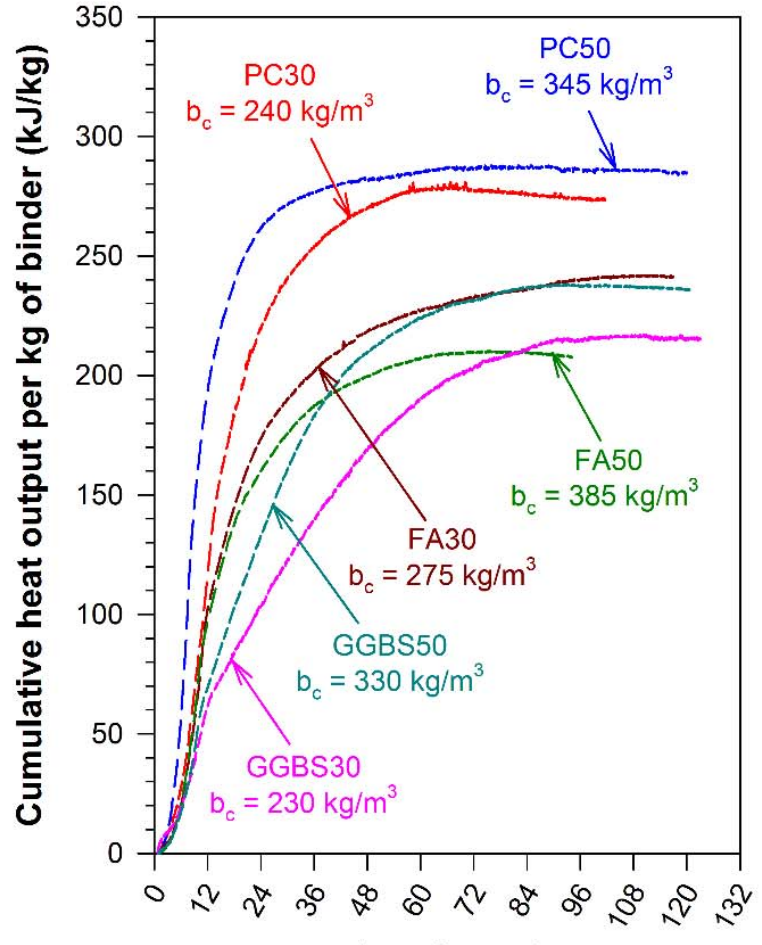

Age (hours)

b) Cumulative heat output

Fig. 5. a) Adiabatic temperature rise of investigated mixes and b) Total cumulative heat output of binder 


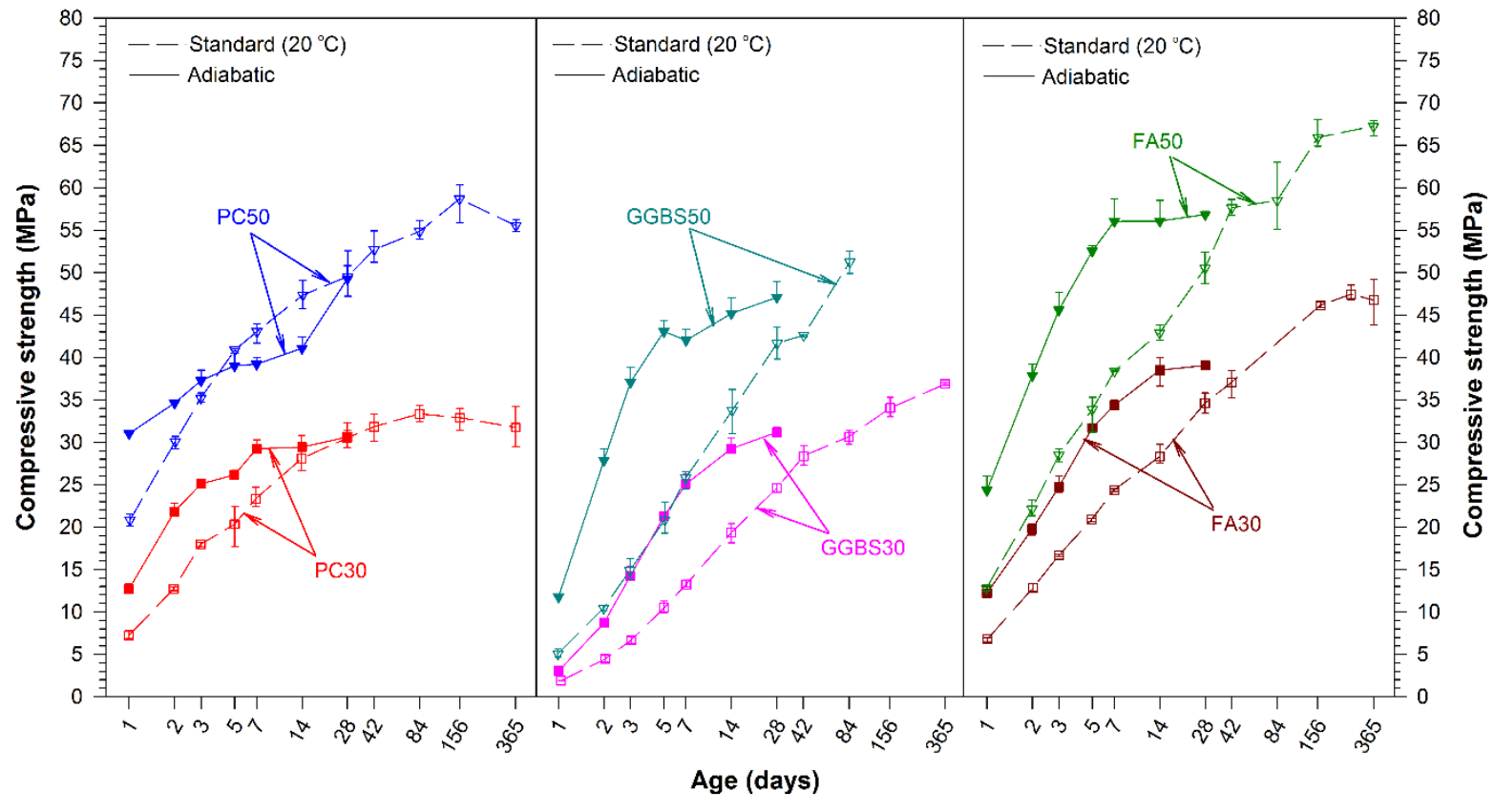

602 Fig. 6. Strength development of standard $\left(20^{\circ} \mathrm{C}\right)\left(\mathrm{S}_{20}{ }^{\circ} \mathrm{C}\right)$ and adiabatically $\left(\mathrm{S}_{\text {adiabatic }}\right)$ cured 603 concretes 
604

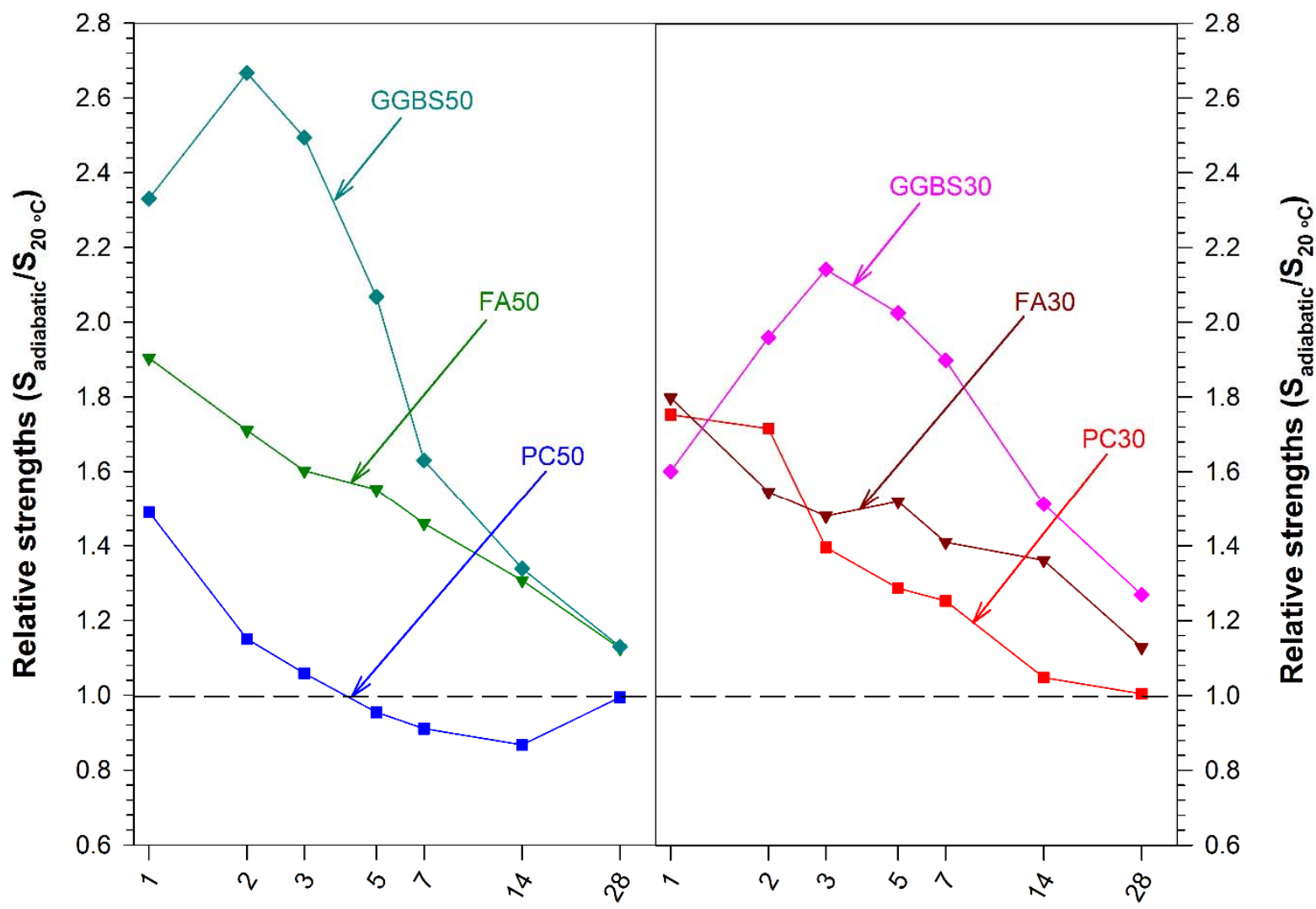

Age (days)

605

a) $50 \mathrm{MPa}$ concretes

b) $30 \mathrm{MPa}$ concretes

606 Fig.

7. Relative

strengths,

i.e.

( $\mathrm{S}_{\text {adiabatic }} / \mathrm{S}_{20}$

$\left.{ }^{\circ} \mathrm{C}\right)$ 
607

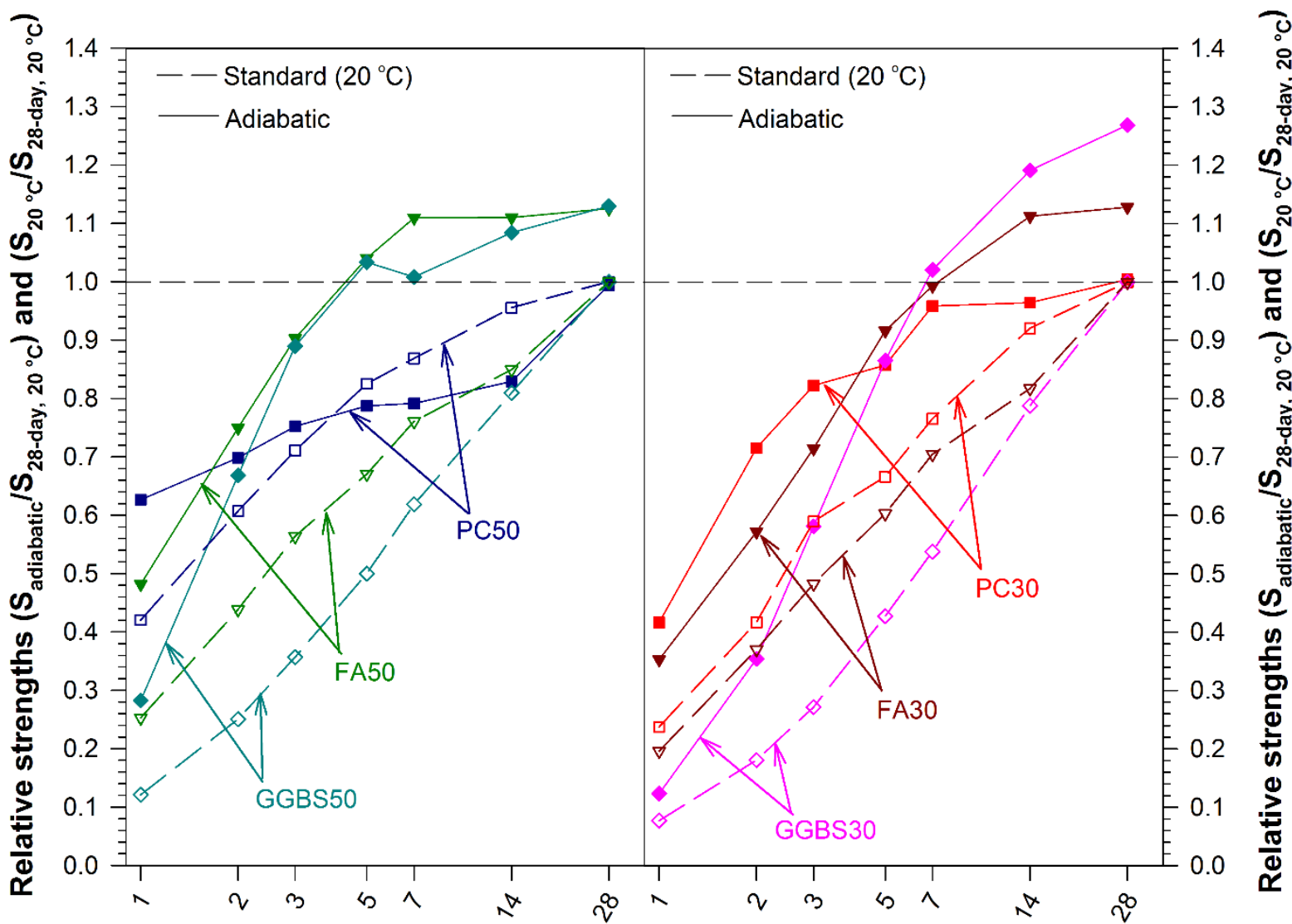

Age (days)

608

a) $50 \mathrm{MPa}$ concretes

b) $30 \mathrm{MPa}$ concretes

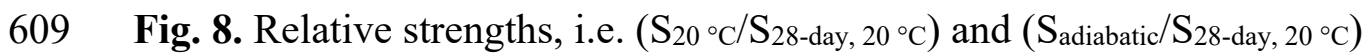


610

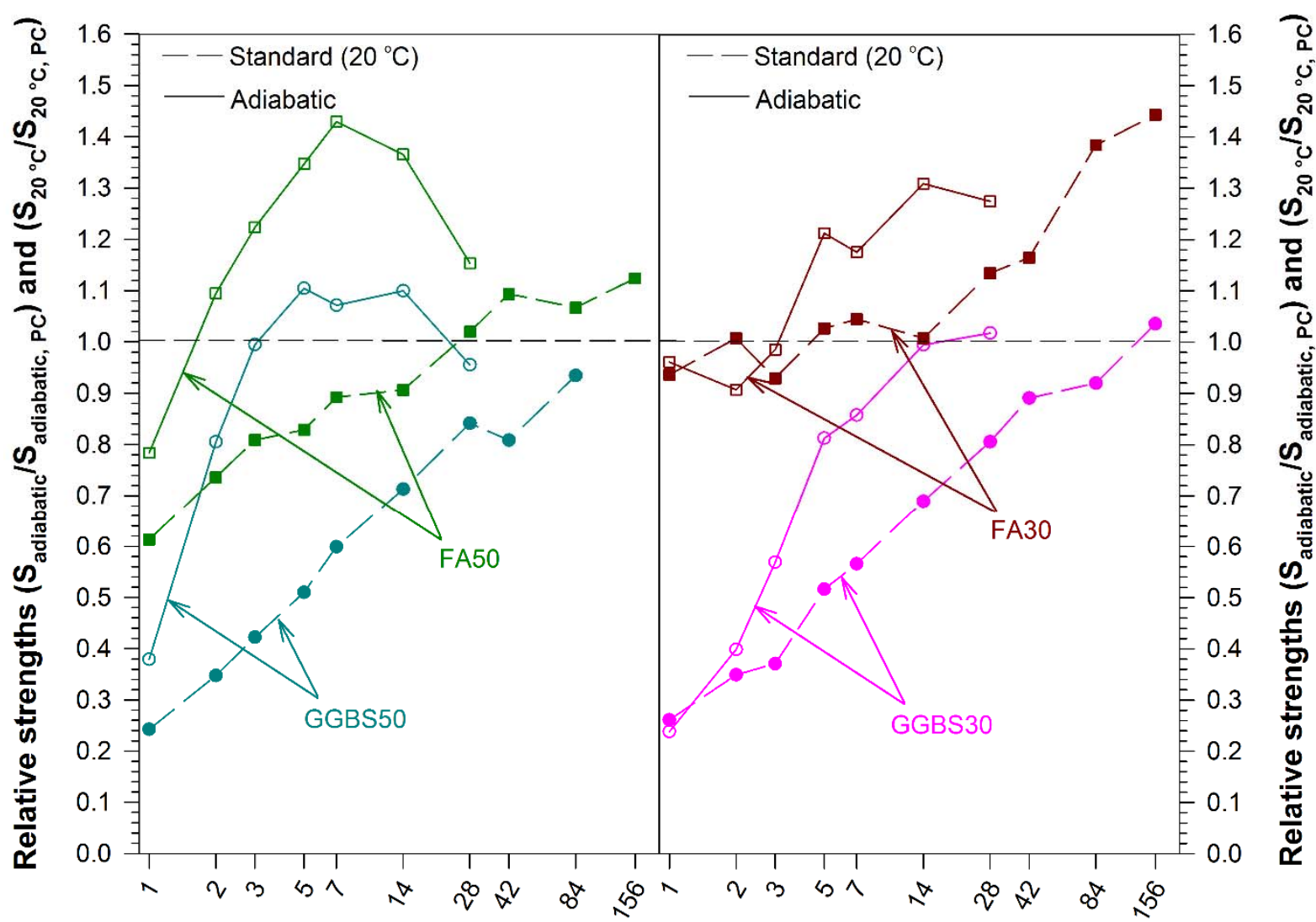

Age (days)

611

a) $50 \mathrm{MPa}$ concretes

b) $30 \mathrm{MPa}$ concretes

612 Fig. 9. Relative strengths, i.e. $\left(\mathrm{S}_{\text {adiabatic }} / \mathrm{S}_{\text {adiabatic, } \mathrm{PC}}\right)$ and $\left(\mathrm{S}_{20}{ }^{\circ} \mathrm{C} / \mathrm{S}_{20}{ }^{\circ} \mathrm{C}, \mathrm{PC}\right)$ 
613

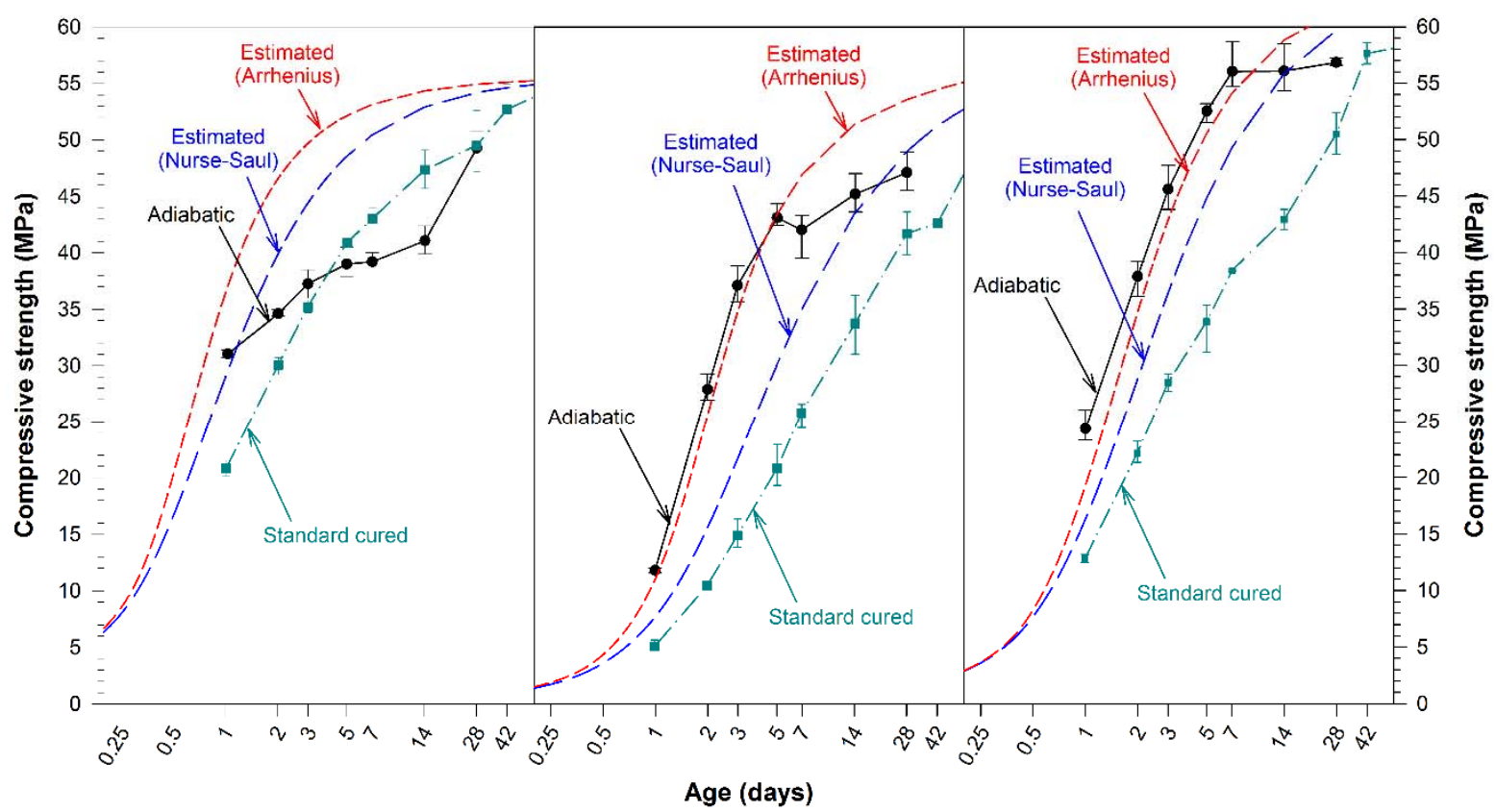

614

a) PC50

b) GGBS50

c) FA50

615 Fig. 10. Adiabatic strength estimates for $50 \mathrm{MPa}$ strength concretes 
616

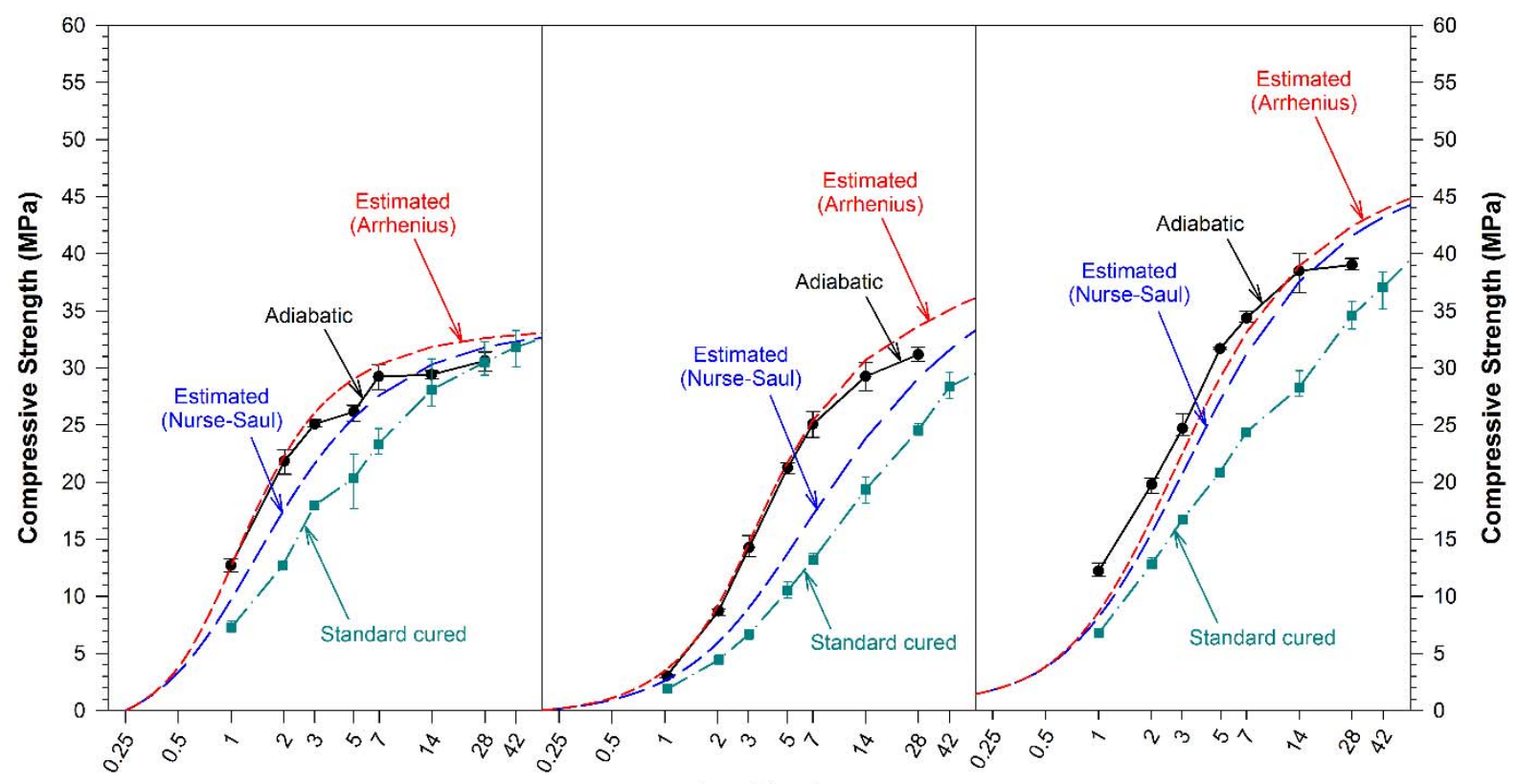

Age (days)

617

a) $\mathrm{PC} 30$

b) GGBS30

c) $\mathrm{FA30}$

618 Fig. 11. Adiabatic strength estimates for $30 \mathrm{MPa}$ strength concretes 


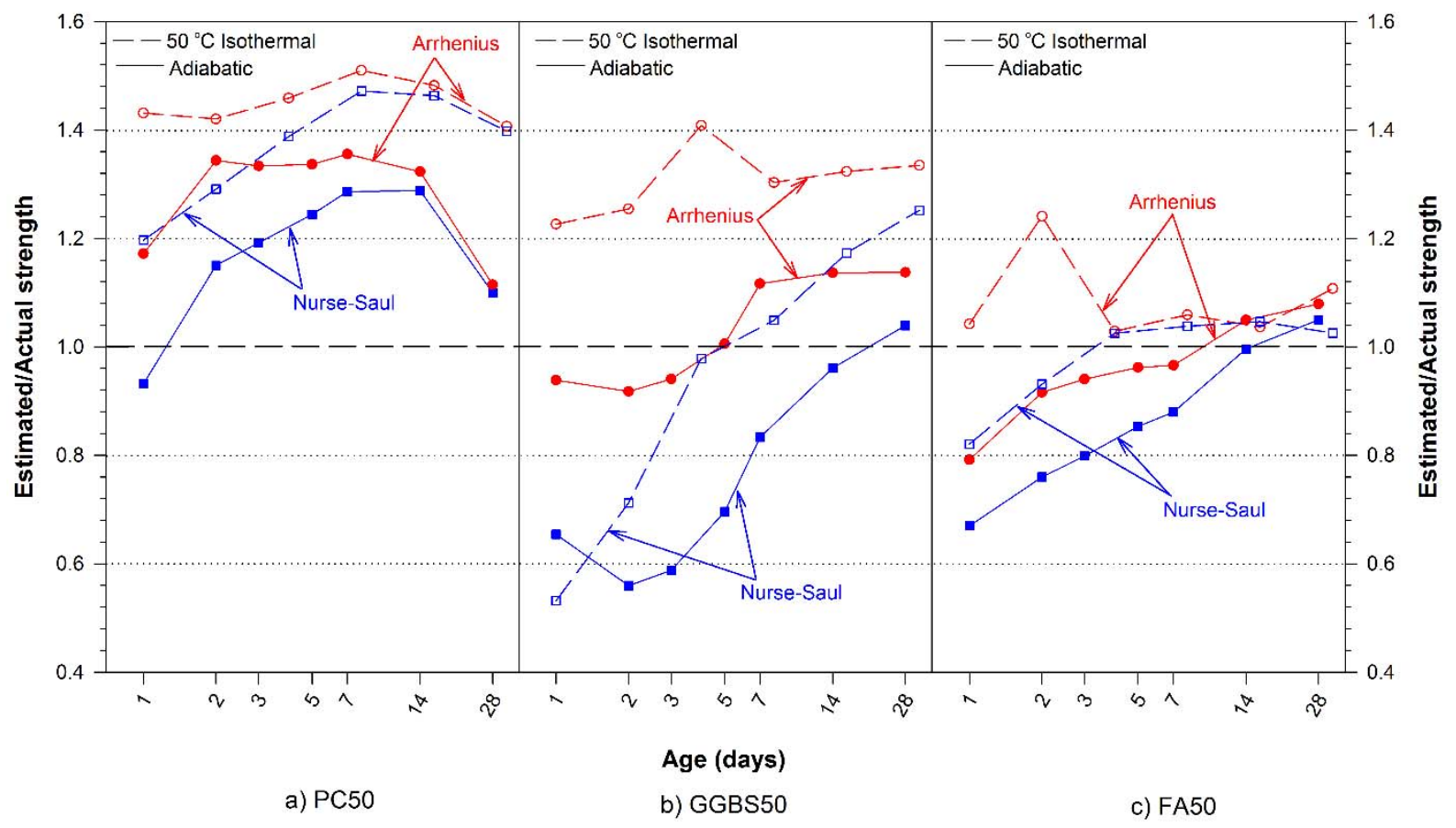

621 Fig. 12. Ratio of estimated/actual strength for $50 \mathrm{MPa}$ strength adiabatically cured concretes

622 and also for their $50^{\circ} \mathrm{C}$ isothermally cured "equivalent" mortars 


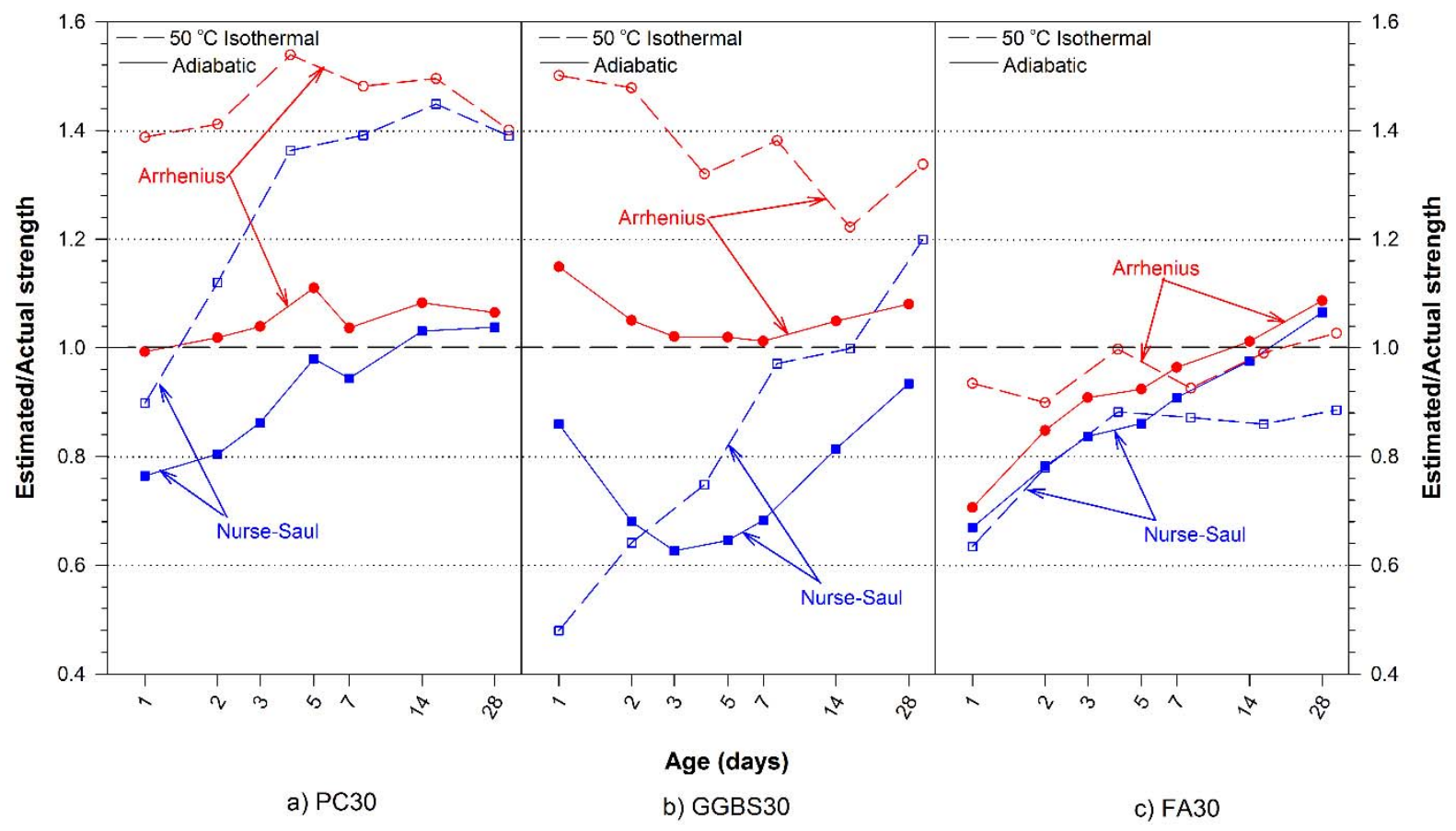

625 Fig. 13. Ratio of estimated/actual strength for $30 \mathrm{MPa}$ strength adiabatically cured concretes

626 and also for their $50{ }^{\circ} \mathrm{C}$ isothermally cured "equivalent" mortars 